\title{
Mekanisme Pembentukan Peraturan Nagari yang Baik (Studi di Nagari Gurun Panjang Kecamatan Bayang Kabupaten Pesisir Selatan Sumatera Barat)
}

\author{
Besse Patmawanti, Naldi Gantika \\ Fakultas Hukum Universitas Ekasakti Padang \\ Correspondence email: bessepatmawanti84@gmail.com; hgantika74@gmail.com
}

\begin{abstract}
Abstrak. Penelitian ini merupakan penelitian deskriptif analitis. Pendekatan yang digunakan adalah pendekatan yuridis normatif yang didukung oleh pendekatan yuridis empiris. Penelitian ini dilakukan di Nagari Gurun Panjang Kecamatan Bayang Kabupaten Pesisir Selatan Sumatera Barat. Teknik pengumpulan data yang digunakan adalah wawancara dan studi kepustakaan. Data yang diperoleh dianalisis secara kualitatif dan diuraikan dalam bentuk deskriptif analisis. Hasil penelitian menunjukkan bahwa: (1) Peraturan Nagari dibentuk oleh pemerintahan nagari, yang terdiri atas Badan Permusyawaratan (BAMUS) Nagari bersama Wali Nagari. Kedudukan Peraturan Nagari dalam tata urutan perundang-undangan diakui sebagai salah satu bentuk ketetapan hukum yang mengikat; (2) pemerintahan nagari Gurun Panjang berwenang mengatur dan mengurus rumah tangganya sendiri, termasuk dalam pembentukan Peraturan Nagari. Usulan pembuatan Peraturan Nagari dapat berasal dari wali nagari yang kemudian dibahas antara wali nagari dan BAMUS Nagari. Setelah disetujui bersama, maka Peraturan Nagari tersebut kemudian dibawa oleh kepala BAMUS Nagari kepada Wali Nagari untuk ditetapkan (dan kemudian disampaikan kepada Bupati melalui Camat sebagai bahan pembinaan dan pengawasan; (3) Sebuah Peraturan nagari terdiri dari beberapa bagian yang tersusun dalam suatu kerangka dan bersifat baku untuk setiap jenis peraturan perundang-undangan. Kerangka Peraturan Nagari terdiri atas 6 (enam) bagian, yaitu: Judul, Pembukaan, Batang Tubuh, Penutup, Penjelasan (jika diperlukan), dan Lampiran (jika diperlukan).
\end{abstract}

Kata kunci: Mekanisme; Pembentukan; Peraturan Nagari

Abstract. This research is descriptive analytic. The method uses in this research is the normative and juridical empiric method. This research is done in Nagari Gurun Panjang Disctrict of Bayang South Pesisir Regency West Sumatera. The techbique of collecting data is interview and document study. Then, the data analyzed qualitatively in descriptive analysis form. The results of research show that: (1) the nagari regulation formed by governance of nagari, consist of BAMUS nagari together walinagari. The existence of nagari regulation in the regulation admitted as one of legal law; (2) the governance of nagari Gurun Panjang has authority and manage his household itself, included in the forming of nagari regulation. The proposal of making nagari regulation can be from walinagari and then discussed between walinagari and BAMUS nagari. After approfing, the nagari regulation then brought by the head of BAMUS nagari to walinagari to be approved (and given to head of regency though head of district; (3) a nagari regulation constists of some parts arranged in a framework. The framework of a nagari regulation concits of six parts; title, introduction, content, closing, explanation (if needed), and attachment (if needed).

Keywords: Mechanism; Forming; Nagari Regulation

\section{PENDAHULUAN}

Sejak diberlakukannya kebijakan otonomi daerah di Indonesia telah membawa sebuah harapan baru bagi perjalanan bangsa ini ke masa depan. Salah satu implikasi sebelum diberlakukannya otonomi daerah adalah adanya belenggu terhadap warga masyarakat hingga ke tingkat desa. Oleh karena itu, adanya perubahan terhadap Pasal 18 Undang-Undang Dasar Tahun 1945, yaitu:

(1) Negara Kesatuan Republik Indonesia dibagi atas daerah-daerah provinsi dan daerah provinsi itu dibagi atas kabupaten dan kota, dan tiap-tiap provinsi, kabupaten, dan kota itu mempunyai pemerintahan daerah yang diatur dengan undang-undang;

(2) Pemerintah daerah provinsi, daerah kabupaten dan kota mengatur dan mengurus sendiri urusan pemerintahan menurut asas otonomi dan tugas pembantuan;

(3) Pemerintahan daerah provinsi, daerah kabupaten, dan kota memiliki Dewan Perwakilan Rakyat Daerah yang angota-anggotanya dipilih melalui pemilihan umum;

(4) Gubernur, Bupati dan Walikota masing-masing sebagai kepala pemerintahan daerah provinsi, kabupaten, dan kota diilih secara demokratis.

(5) Pemerintahan daerah menjalankan otonomi seluas-luasnya, kecuali urusan pemerintahan yang oleh undangundang ditentukan sebagai urusan Pemerintah Pusat;

(6) Pemerintahan daerah berhak menetapkan peraturan daerah dan peraturan-peraturan lain untuk melaksanakan otonomi dan tugas pembantuan;

(7) Susunan dan tata cara penyelenggaraan pemerintahan daerah diatur dalam undang-undang. 
Sesuai dengan ketentuan dalam Pasal 18 UUD 1945 di atas pemerintah daerah kemudian diberikan kewenangan untuk mengatur serta mengurus sendiri urusan pemerintahan daerahnya menurut asas otonomi dan tugas perbantuan. Hal ini sesuai dengan pendapat yang dikemukakan oleh Otong Rosadi, bahwa diberikannya hak perundang-undangan dan pemerintah kepada badan otonomi, seperti kepada propinsi, kabupaten dan kota mengandung pengertian bahwa badan tersebut dengan inisiatifnya sendiri dapat mengurus rumah tangganya dengan membuat peraturan sendiri ${ }^{1}$.

Senada dengan dikemukakan oleh Amrah Muslimin bahwa pemberian otonomi luas kepada daerah diarahkan dalam rangka mempercepat terwujudnya kesejahteraan masyarakat melalui peningkatan pelayanan, pemberdayaan, dan peran serta masyarakat. Selain itu, melalui pemberian otonomi luas, diharapkan daerah mampu meningkatkan daya saing dengan memperhatikan prinsip demokrasi, pemerataan, keadilan, keistimewaan dan kekhususan serta potensi keanekaragaman daerah dalam sistem Negara Kesatuan Republik Indonesia ${ }^{2}$.

Dengan mengacu kepada kedua pendapat di atas, maka prinsip otonomi daerah menggunakan prinsip otonomi seluas-luasnya diartikan bahwa daerah diberikan kewenangan untuk mengurus dan mengatur semua urusan pemerintahan di luar yang menjadi urusan pemerintah yang ditetapkan dalam undang-undang. Daerah diberikan kewenangan untuk mengeluarkan kebijakan daerah untuk memberi pelayanan, peningkatan peran serta, prakarsa, dan pemberdayaan masyarakat yang bertujuan pada peningkatan kesejahteraan masyarakat. ${ }^{3}$

Wujud dari demokrasi adalah diberikannya wewenang kepada daerah untuk mengatur rumah tangga daerahnya sendiri, salah satunya adalah dalam bidang pemerintahan bersih dan berwibawa yang orientasinya adalah kepentingan publik. Untuk mencapai hal tersebut, maka arah dan kebijakan pemerintahan daerah harus bisa melakukan perubahan mendasar secara internal dengan orientasi terhadap perubahan dan perkembangan lingkungan masyarakatnya. ${ }^{4}$

Implikasi dari bentuk pemberian wewenang kepada daerah untuk mengatur rumah tangga daerahnya dalam bidang pemerintahan adalah pemberian otonomi dalam sistem pemerintahan terendah yang dikenal dengan istilah desa. Bentuk pemberian wewenang kepada daerah untuk mengatur rumah daerahnya dalam bidang pemerintahan adalah pemberian otonomi dalam sistem pemerintahan terendah, seperti pemberlakuan sistem pemerintahan nagari yang berlaku di Sumatera Barat yang dikenal dengan nama kembali ke nagari.

Menurut Pasal 1 butir (1) Undang-Undang Nomor 6 Tahun 2014 menyebutkan bahwa: desa adalah desa dan desa adat atau yang disebut dengan nama lain, selanjutnya disebut desa adalah kesatuan masyarakat hukum yang memiliki batas wilayah yang berwenang untuk mengatur dan mengurus urusan pemerintahan, kepentingan masyarakat setempat berdasarkan prakarsa masyarakat, hak asal usul, dan/atau hak tradisional yang diakui dan dihormati dalam sistem pemerintahan Negara Kesatuan Republik Indonesia.

Disahkannya Undang-Undang Nomor 6 Tahun 2014 pada tanggal 15 Januari 2014 menjadi payung hukum terhadap penyelenggaraan desa. Salah satu bagian sangat penting dalam Undang-Undang tentang Desa tersebut adalah adanya pengaturan tentang Peraturan Desa. Lebih lanjut diatur dalam Pasal 69 Undang-Undang tentang Desa bahwa "Jenis Peraturan Desa terdiri atas Peraturan Desa, peraturan bersama Kepala Desa, dan peraturan Kepala Desa". Dalam hal pembentukan Peraturan Perundang-Undangan secara teknis merujuk kepada Undang-Undang Nomor 12 Tahun 2011 tentang Pembentukan Peraturan Perundang-Undangan. Juga diatur dalam Pasal 69 ini bahwa "Rancangan Peraturan Desa wajib dikonsultasikan kepada masyarakat Desa" dan "Masyarakat desa berhak memberikan masukan terhadap Rancangan Peraturan Desa".

Berdasarkan Undang-Undang Nomor 10 tahun 2004 tentang Pembentukan Peraturan Perundang-Undangan Negara Republik Indonesia yang telah dirubah dengan Undang-Undang Nomor 12 Tahun 2011 dan Undang-Undang Nomor 15 Tahun 2019 tentang Perubahan Atas Undang-Undang Nomor 12 Tahun 2011 tentang Pembentukan Peraturan Perundang-Undangan, peraturan perundang-undangan yang paling rendah kedudukannya adalah Peraturan Desa (Peraturan Nagari), dalam hal ini untuk wilayah Propinsi Sumatra Barat yang memiliki pemerintahan paling kecil yaitu Pemerintahan Nagari, jadi disebut Peraturan Nagari (PERNA). Peraturan Nagari di sini memiliki kedudukan paling rendah, akan tetapi kedudukannya digolongkan sebagai Peraturan Daerah Propinsi dan juga Peraturan Daerah Kabupaten/kota, karena sama-sama bagian dari pemerintahan daerah.

Kemudian berdasarkan hal di atas maka pemerintah pada tanggal 12 agustus 2011 secara resmi mengundangkan Undang-Undang Nomor 12 Tahun 2011 Tentang Pembentukan Peraturan Perundang-Undangan sebagai pengganti dari Undang-Undang Nomor 10 Tahun 2004 Tentang Pembentukan Peraturan Perundangundangan. Dengan berlakunya Undang-Undang Nomor 12 Tahun 2011, maka Undang-Undang Nomor 10 Tahun 2004

1 Otong Rosadi, Hukum Tata Negara Indonesia; Teori dan Praktek, (Naskah Untuk Program Penulisan Buku Teks Perguruan Tinggi), (Padang: Fakultas Hukum Universitas Ekasakti, 2004), hlm. 67

${ }^{2}$ Amrah Muslimin, Otonomi Daerah: Antara Cita dan Realita, Jurnal Sosial Politik Dialektika, Vol. 29 No. 29 (Juli 2009), hlm. 17

${ }^{3}$ Ibid, hlm. 18

${ }^{4}$ Inu Kencana Syafi'i, Sistem Pemerintahan Indonesia dari Orde Lama Hinggga Era Reformasi, Jakarta: Rineka Cipta, 2007), hlm. 3 
dinyatakan dicabut dan tidak berlaku lagi Berdasarkan Undang-Undang Nomor 12 Tahun 2011 tentang Pembentukan Peraturan Perundang-undangan diatas, jelas kalau Peraturan Nagari tidak mempunyai kedudukan dalam tata urutan peraturan perundang-undangan Negara Republik Indonesia. Dengan berlakunya Undang-Undang Nomor 12 Tahun 2011 tentang Pembentukan Peraturan Perundang-undangan tersebut, tidak dapat dihindarkan lagi timbul banyak pertanyaan-pertanyaan, yaitu tentang kedudukan Peraturan Nagari. Mengingat Peraturan Nagari itu sangat penting, salah satu yang diatur dalam Peraturan Nagari itu adalah mengenai Anggaran Pendapatan dan Belanja Nagari, sedangkan menurut tata urutan Peraturan Perundang-undangan yang berlaku saat ini tidak mempunyai kedudukan lagi. Selain itu Bamus Nagari dalam pembetukan Peraturan Nagari akan kehilangan kewenangannya dan bagaimana dengan keputusan Wali Nagari, apakah masih tetap berlaku atau tidak.

Tulisan ini berupaya melengkapi, mengkonfirmasi hingga memberikan penjelasan tentang kedudukan peraturan nagari, kewenangan pembentukan peraturan nagari serta kerangka peraturan nagari. Melalui uraian ini diharapkan memberikan penjelasan terkait dengan mekanisme pembentukan Peraturan Nagari yang baik khususnya di Nagari Gurun Panjang Kecamatan Bayang Kabupaten Pesisir Selatan yang saat ini menjadi percontohan di beberapa nagari di sekitarnya. Penelitian ini menjadi urgen untuk dilakukan sebagai solusi dalam menentukan kerangka peraturan nagari yang baik. Banyak pemerintah nagari yang masih memiliki kendala dalam melakukan pembentukan peraturan nagari terutama berkaitan dengan kerangka peraturan nagari.

\section{METODE}

Penelitian ini merupakan penelitian deskriptif analitis. Menurut Soerjono Soekanto, penelitian deskriptif analitis bertujuan menggambarkan apa adanya secara tepat sifat-sifat suatu individu, keadaan, gejala, atau kelompok tertentu, atau untuk menentukan penyebaran sutau gejala, atau untuk menentukan ada tidaknya hubungan antara suatu gejala dengan gejala lain dalam masyarakat ${ }^{5}$. Menurut Farid Ali, penelitian deskriptif analitis merupakan metode penelitian yang melukiskan secara tepat sifat-sifat individu, suatu keadaan, suatu gejala dan sebagainya yang merupakan obyek penelitian ${ }^{6}$.

Berdasarkan hal tersebut, maka penelitian ini dimaksudkan untuk memberikan data dan gambaran terhadap masalah yang diteliti baik keadaan atau gejala-gejala maupun akibatnya, yaitu berhubungan dengan Mekanisme Pembentukan Peraturan Nagari yang Baik (Studi di Nagari Gurun Panjang Kecamatan Bayang Kabupaten Pesisir Selatan Sumatera Barat).

Pendekatan yang digunakan dalam penelitian ini adalah pendekatan yuridis normatif yang didukung oleh pendekatan yuridis empiris. Pendekatan yuridis empiris menurut Ronny Hanitijo Soemitro artinya adalah mengidentifikasikan dan mengkonsepsikan hukum sebagai institusi sosial yang riil dan fungsional dalam sistem kehidupan yang mempola. Sementara J. Supranto mengatakan bahwa penelitian yuridis empiris adalah penelitian yang condong bersifat kuantitatif, berdasarkan data primer. Data primer adalah data yang diperoleh secara langsung dari objeknya ${ }^{7}$. Pendekatan yuridis normatif dalam penelitian ini digunakan untuk menguraikan bahan-bahan kepustakaan berupa peraturan perundang-undangan, buku-buku dan hasil penelitian yang terkait dengan masalah yang diteliti. Sedangkan pendekatan yuridis empiris digunakan untuk mengetahui bekerjanya hukum dalam masyarakat mengenai Mekanisme Pembentukan Peraturan Nagari yang Baik (Studi di Nagari Gurun Panjang Kecamatan Bayang Kabupaten Pesisir Selatan Sumatera Barat).

Penelitian ini dilakukan di Nagari Gurun Panjang Kecamatan Bayang Kabupaten Pesisir Selatan Sumatera Barat sebagai salah satu nagari yang menjadi percontohan pembuatan peraturan nagari oleh beberapa nagari di sekitarnya. Teknik pengumpulan data yang digunakan adalah melalui wawancara dan studi kepustakaan. Data yang diperoleh kemudian dianalisis secara kualitatif serta diuraikan dalam bentuk deskriptif analisis.

\section{HASIL DAN PEMBAHASAN \\ Pembentukan Peraturan Nagari yang Baik \\ Kedudukan Peraturan Nagari}

Menurut Imran Manan seperti dikutip Alfar Arbi bahwa nagari merupakan sebuah negara mini (kecil) di dalam kerajaan Minangkabau masa lalu. Nagari memiliki birokrasi pemerintahan yang tiada sama di antara mereka, walaupun secara asas mereka sama-sama berasaskan demokrasi, akan tetapi struktur pemerintahannyanya terkadang berbeda. Namun secara asas politik dan ideologi seluruh nagari memiliki fungsi dan tujuan yang sama. Nagari

\footnotetext{
${ }^{5}$ Soerjono Soekanto, Faktor-faktor yang Mempengaruhi Penegakan Hukum, (Jakarta: PT Raja Grafindo Persada, 2004), hlm. 24

${ }^{6}$ Farid Ali, Metode Penelitian Sosial dalam Bidang Ilmu Administrasi Negara dan Pemerintahan, (Jakarta: Raja Grafindo Persada, 1997), hlm. 55

${ }^{7}$ Ronny Hanitijo Soemitro, Metodologi Penelitian Hukum dan Jurimetri, Cetakan Kelima, Jakarta: Ghalia Indonesia, 1994), hlm. 12
} 
merupakan sebuah wilayah merdeka. Artinya, ia memiliki kemerdekaan daripada ekonomi, adat-istiadat, budaya, politik dan sosial serta hak asasi manusia ${ }^{8}$.

Sebagai wilayah berdaulat dan memiliki kemerdekaan nagari merupakan sebuah daerah birokrasi pemerintahan yang mengendalikan dan mengurusi pelbagai wujud persoalan kepemerintahan, seperti sistem politik, ekonomi, kemanusiaan, budaya dan peradaban, maupun kepercayaan (agama/religius). Oleh karena itu, nagari memiliki undangundang, aturan dan sistem pemerintahan serta ideologi serta aparatur pemerintahan (kaki tangan dan pegawai) maupun pengetua (pimpinan) yang akan menjalankan pemerintahan.

Nagari di Sumatera Barat berarti desa, sehingga peraturan nagari sama dengan peraturan desa. Jika peraturan desa dibuat oleh pemerintah desa, yang terdiri atas Badan Permusyawaratan Desa (BPD) bersama Kepala Desa, maka Peraturan Nagari di Sumatera Barat dibentuk oleh pemerintahan nagari, yang terdiri atas Badan Permusyawaratan (BAMUS) Nagari atau Badan Permusyawaratan Rakyat Nagari (BPRN) bersama Wali Nagari. Peraturan Desa tidak memerlukan pengesahan Bupati tetapi wajib disampaikan kepada Bupati selambat-lambatnya 2 (dua) minggu setelah ditetapkan dengan tembusan kepada camat. Pelaksanaan Peraturan Desa ditetapkan dengan Keputusan Kepala Desa. ${ }^{9}$

Kedudukan Peraturan Nagari dalam tata urutan perundang-undangan diakui sebagai salah satu bentuk ketetapan hukum yang mengikat, di mana dalam hal ini pembentukan dan muatan materinya harus disesuaikan dan tidak boleh bertentangan dengan kepentingan umum serta peraturan hukum yang lebih tinggi.

Peratuan Nagari dibentuk dalam rangka penyelenggaraan pemerintahan nagari karena keberadaan Peraturan Nagari menjadi penting sebagai check and balances bagi pemerintah nagari dan BAMUS Nagari. Oleh karena kedudukan Peraturan Nagari sangat penting, maka penyusunan Peraturan Nagari tersebut harus didasarkan kepada kebutuhan dan kondisi nagari setempat serta tidak boleh bertentangan dengan peraturan perundangan yang lebih tinggi dan tidak boleh merugikan kepentingan umum. Peraturan Nagari juga sebagai produk politik yang harus disusun secara demokratis dan partisipatif.

Sebagai mitra pemerintah nagari, BAMUS Nagari dalam pelaksanaan peraturan nagari mempunyai hak untuk melakukan pengawasan dan evaluasi terhadap hasil pelaksanaan peraturan nagari tersebut, sedangkan masyarakat sebagai penerima dari Peraturan Nagari juga mempunyai hak untuk melakukan monitoring dan evaluasi terhadap pelaksanaan Peraturan Nagari.

Eksistensi Peraturan nagari kini memiliki dasar hukum yang jelas dan kuat. Menurut Pasal 26 ayat (2) huruf d Undang-Undang tentang Desa mengatur bahwa "Kepala Desa/Wali Nagari (Sumatera Barat) berwenang menetapkan Peraturan Nagari. Kemudian Pasal 55 huruf a Undang-Undang tentang Desa mengatur bahwa Badan Permusyawaratan Desa/Bamus nagari mempunyai fungsi "membahas dan menyepakati Rancangan Peraturan Desa bersama".

Setelah berlakunya Undang-Undang Nomor 12 Tahun 2011, walinagari Gurun Luas masih berwenang dalam pembentukan peraturan nagari dan tidak ada intervensi dari pihak lain. Dengan adanya otonomi daerah, kewenangan Bamus sebagai lembaga legislatif di tingkat nagari, Bamus (Badan Musyawarah) Nagari Gurun Panjang berfungsi sebagai pengawas sekaligus menampung dan menyalurkan aspirasi masyarakat yang masih berwenang membuat peraturan nagari setelah diberlakukannya Undang-Undang Nomor 12 Tahun 2011. Sebagai lembaga legislative dalam pembentukan peraturan nagari, Bamus Nagari Gurun Panjang memperhatikan serta mempertimbangkan kondisi masyarakat nagari Gurun Panjang.

\section{Kewenangan Pembentukan Peraturan Nagari}

Sebelum menguraikan tentang kewenangan pembentukan Peraturan Nagari, penulis menjelaskan terlebih dahulu mengenai kewenangan. Menurut Marbun, kewenangan (authority, gezaq) adalah kekuasaan yang diformalkan baik terhadap sesuatu bidang pemerintahan tertentu secara bulat yang berasal dari kekuasaan legislatif maupun kekuasaan dari pemerintah, sedangkan wewenang (competence, bevoeggdheid) hanya mengenai onderdil tertentu saja. ${ }^{10}$

Sejak dikeluarkannya kebijakan otonomi daerah, banyak pemerintah daerah yang membuat Peraturan Daerah yang materi muatannya disesuaikan dengan keadaan dan kebutuhan masyarakat setempat. Salah satunya adalah Sumatera Barat yang membentuk Perda sesuai dengan keadaan dan kebutuhan masyarakatnya.

Nagari Gurun Panjang Kecamatan Bayang Kabupaten Pesisir Selatan merupakan salah satu nagari yang ada di Sumatera Barat. Dengan diberlakukannya otonomi daerah, pemerintahan nagari Gurun Panjang berwenang mengatur dan mengurus rumah tangganya sendiri, termasuk dalam pembentukan Peraturan Nagari. Sesuai dengan ketentuan

\footnotetext{
${ }^{8}$ Alfar Arbi, Sistem Pemerintahan Nagari di Sumatera Barat, (Padang: Angkasa, 1999), hlm. 27

${ }^{9}$ Deddy Supriady Bratakusumah, Otonomi Penyelenggaraan Pemerintah Daerah, Cet ke3 (Jakarta: Gramedia Pustaka Utama, Juni 2002), lm. 27 hlm. 154

${ }^{10}$ Marbun, "Peradilan Administrasi dan Upaya Administratif di Indonesia", Cet ke-1 (Yogyakarta: Liberty,1997),
} 
Pasal 18 A ayat (1) UUD 1945 menyatakan: "Hubungan wewenang antara pemerintah pusat dengan pemerintah daerah provinsi, kabupaten dan kota.

Usulan pembuatan Peraturan Nagari dapat berasal dari wali nagari yang kemudian dibahas antara wali nagari dan BAMUS Nagari. Setelah disetujui bersama, maka Peraturan Nagari tersebut kemudian dibawa oleh kepala BAMUS Nagari kepada Wali Nagari untuk ditetapkan (berlaku sejak ditetapkan) dan kemudian disampaikan kepada Bupati melalui Camat sebagai bahan pembinaan dan pengawasan.

Hasil penelitian yang dilakukan menunjukkan bahwa dalam penyelenggaraan pemerintahan nagari Gurun Panjang, BAMUS sebagai lembaga legislatif di tingkat pemerintahan nagari memiliki kewenangan membentuk peraturan nagari. Dalam penyelenggaraan pemerintahan, pemerintah nagari Gurun Panjang tidak hanya dijalankan oleh BAMUS Nagari dengan walinagari saja, akan tetapi dibantu oleh bidang lain, seperti bidang bagian pemerintahan. Bagian pemerintahan sebagai salah satu dari unsur-unsur bidang yang ada dalam pemerintahan nagari, bagian pemerintahan juga berperan penting dalam penyelenggaraan pemerintahan nagari Gurun Panjang. Dalam penyelenggaraan pemerintahan nagari Gurun Panjang, bidang pemerintahan membantu dalam administrasi seperti pengurusan KTP serta membentuk Anggaran Pendapatan Belanja Nagari (APB Nagari) dan pengarsipan lainnya. Adapun dalam hal pembentukan peraturan nagari, bidang pemerintahan membantu sekretaris nagari dalam mengarsipkan peraturan nagari yang sudah ditetapkan. Apabila peraturan nagari sudah ditetapkan oleh BAMUS Nagari dan perangkat adat lainnya, maka bidang pemerintahan dan sekretaris menulis dan mengarsipkan peraturan nagari tersebut.

\title{
Kerangka Peraturan Nagari
}

Sebuah Peraturan nagari terdiri dari beberapa bagian yang tersusun dalam suatu kerangka dan bersifat baku untuk setiap jenis peraturan perundang-undangan. Kerangka Peraturan Nagari terdiri atas 6 (enam) bagian, yaitu: Judul, Pembukaan, Batang Tubuh, Penutup, Penjelasan (jika diperlukan), dan Lampiran (jika diperlukan).

\section{a. Judul}

Judul peraturan nagari merupakan frase yang menyatakan gambaran pokok substansi, memuat jenis (dan nama nagari), nomor, tahun pengundangan atau penetapan, dan nama peraturan nagari. Judul peraturan nagari ditulis seluruhnya dengan huruf besar (kapital), diletakkan di tengah margin, dan tanpa diakhiri tanda baca.

Contoh:

\section{PERATURAN NAGARI GURUN PANJANG \\ NOMOR 10 TAHUN 2010 \\ TENTANG \\ PASAR}

Pada judul peraturan NAGARI perubahan atau peraturan nagari yang mengubah peraturan nagari sebelumnya ditambahkan frase 'PERUBAHAN ATAS' di depan nama peraturan nagari yang diubah.

Contoh:

\author{
PERATURAN NAGARI GURUN PANJANG \\ NOMOR 10 TAHUN 2010 \\ TENTANG \\ PERUBAHAN ATAS PERATURAN NAGARI NOMOR 1 TAHUN 2008 \\ TENTANG PASAR
}

Jika suatu peraturan daerah telah diubah lebih dari 1 (satu) kali, di antara kata 'PERUBAHAN' dan kata 'ATAS' disisipkan keterangan yang menunjukkan berapa kali perubahan tersebut telah dilakukan, tanpa merinci perubahan sebelumnya.

Contoh:

\author{
PERATURAN NAGARI GURUN PANJANG \\ NOMOR ...... TAHUN ....... \\ TENTANG \\ PERUBAHAN KETIGA ATAS PERATURAN NAGARI \\ NOMOR .... TAHUN ..... \\ TENTANG
}


Pada peraturan NAGARI yang mencabut peraturan nagari sebelumnya tanpa adanya penggantian peraturan nagari yang baru, maka judul peraturan nagari tersebut disisipkan kata 'PENCABUTAN' di depan nama peraturan nagari yang disabut.

Contoh:

\author{
PERATURAN NAGARIGURUN PANJANG \\ NOMOR ..... TAHUN ....... \\ TENTANG \\ PENCABUTAN PERATURAN DAERAH NOMOR .... TAHUN ..... \\ TENTANG
}

\title{
b. Pembukaan
}

Pembukaan Pernagterdiri atas frase 'Dengan Rahmat Tuhan Yang Maha Esa', Jabatan Wali Nagari, Konsiderans, Dasar Hukum, dan Diktum.

Frase 'DENGAN RAHMAT TUHAN YANG MAHA ESA'

Frase 'DENGAN RAHMAT TUHAN YANG MAHA ESA' dicantumkan setelah judul peraturan nagari dan sebelum nama jabatan pembentuk peraturan nagari yang ditulis seluruhnya dengan huruf besar (kapital) dan diletakkan di tengah margin.

Contoh:

\author{
PERATURAN NAGARI GURUN PANJANG \\ NOMOR 10 TAHUN 2010 \\ TENTANG \\ RETRIBUSI PASAR
}

DENGAN RAHMAT TUHAN YANG MAHA ESA

\section{c. Jabatan Pembentuk Peraturan nagari}

Jabatan pembentuk peraturan nagari ditulis seluruhnya dengah huruf besar (kapital) yang diletakkan di tengah margin, setelah frase 'DENGAN RAHMAT TUHAN YANG MAHA ESA', dan diakhiri dengan tanda baca koma.

Contoh:

\author{
PERATURAN NAGARI GURUN PANJANG \\ NOMOR 10 TAHUN 2010 \\ TENTANG \\ RETRIBUSI PASAR \\ DENGAN RAHMAT TUHAN YANG MAHA ESA
}

WALI NAGARI GURUN PANJANG

\section{d. Konsideran}

Konsiderans (pertimbangan) memuat uraian singkat mengenai pokok-pokok pikiran yang menjadi latar belakang dan alasan pembuatan peraturan nagari yang dirumuskan dalam rangkaian kalimat yang merupakan kesatuan pengertian dan dicantumkan antara jabatan pembentuk peraturan nagari dan Dasar Hukum. Pokok-pokok pikiran pada konsiderans memuat unsur filosofis, sosiologis, dan yuridis. Dalam merumuskan konsiderans, perlu memperhatikan hal-hal sebagai berikut:

1. Konsideran diawali dengan kata 'Menimbang';

2. Setelah tanda baca titik dua (:) pada kata 'Menimbang', diikuti dengan penulisan pokok-pokok pikiran yang masing-masing diawali huruf alfabet dengan huruf kecil (a, b, c, dan seterusnya) dan dirumuskan dalam satu kalimat yang diawali dengan kata 'bahwa' dan diakhiri dengan tanda baca titik koma;

3. Setiap pokok pikiran dirumuskan dalam rangkaian kalimat yang merupakan kesatuan pengertian;

4. Konsiderans ditutup dengan kesimpulan bahwa peraturan nagari yang hendak dibuat memang diperlukan dengan butir pertimbangan terakhir berbunyi, 'bahwa berdasarkan pertimbangan sebagaimana dimaksud dalam huruf ..., huruf..., dan huruf...., perlu membentuk Peraturan nagari tentang ..........' 
Besse Patmawanti dan Naldi Gantika, Mekanisme Pembentukan Peraturan Nagari yang Baik (Studi di Nagari Gurun Panjang Kecamatan Bayang Kabupaten Pesisir Selatan Sumatera Barat)

\section{Contoh:}

Menimbang:

a. bahwa pembinaan dan pengembangan Koperasi, Usaha Mikro, Usaha Kecil dan Usaha Menengah mempunyai kedudukan dan peran strategis dalam rangka mewujudkan struktur perekonomian yang seimbang;

b. bahwa dalam pelaksanaan Otonomi Daerah diperlukan peranan pemerintah daerah untuk meningkatkan pembinaan dan pengembangan Koperasi, Usaha Mikro dan Usaha Menengah agar mampu mewujudkan peran secara optimal dalam pembangunan ekonomi nagari Gurun Panjang;

c. bahwa berdasarkan pertimbangan sebagaimana dimaksud dalam huruf a dan huruf b, perlu membentuk Peraturan nagari tentang Pasar;

\section{e. Dasar Hukum}

Dasar hukum memuat peraturan perundang-undangan yang lebih tinggi atau setingkat dengan peraturan nagari, meliputi: dasar kewenangan pembuatan peraturan nagari, undang-undang yang secara tegas memerintahkan pembuatan peraturan nagari, undang-undang yang terkait dengan substansi yang akan diatur dalam peraturan nagari, dan peraturan nagari yang mempunyai keterkaitan secara langsung dengan substansi yang akan diatur dalam peraturan nagari yang akan dibentuk.Dengan lain perkataan, dasar hukum berisi kumpulan peraturan perundang-undangan yang lebih tinggi dan/atau setingkat dan masih berlaku serta memiliki kaitan langsung dengan peraturan nagari yang akan dibentuk.

Secara teknis, UU No. 12 Tahun 2011 memberikan pedoman dalam menyusun dasar hukum suatu peraturan nagari, yaitu:

1. Diawali dengan kata 'Mengingat';

2. Memuat dasar kewenangan pembuatan peraturan perundang-undangan dan peraturan perundang-undangan yang memerintahkan pembuatan peraturan nagari yang tingkatannya sama atau lebih tinggi;

3. Peraturan Nagari yang akan dicabut dengan peraturan nagari yang akan dibentuk, atau peraturan nagari yang sudah diundangkan tetapi belum resmi berlaku, tidak dicantumkan sebagai dasar hukum;

4. Peraturan Perundang-undangan yang dicantumkan sebagai dasar hukum disusun sesuai tingkatan dan secara kronologis berdasarkan saat pengundangan atau penetapannya;

5. Penulisan dasar hukum yang memuat lebih dari satu peraturan perundang-undangan, tiap dasar hukum diawali dengan angka Arab 1, 2, 3, dan seterusnya, diakhiri dengan tanda baca titik koma;

6. Dasar hukum yang diambil dari satu pasal atau lebih dalam UUD 1945 ditulis dengan menyebut pasal-pasal yang berkaitan, sedangkan dasar hukum yang bukan dari UUD 1945 tidak perlu mencantumkan pasal, tetapi cukup mencantumkan nama judul undang-undang dengan dilengkapi pencantuman Lembaran Negara dan Tambahan Lembaran Negara yang diletakkan di antara tanda baca kurung.

\section{Contoh:}

Mengingat:

1. Pasal ... ayat (...) dan Pasal ... Undang-Undang Dasar Negara Republik Indonesia Tahun 1945;

2. Undang-Undang Nomor .... Tahun .... Tentang ..... (Lembaran Negara Republik Indonesia Tahun .... Nomor ...., Tambahan Lembaran Negara Republik Indonesia Nomor ....

3. .... dst

\section{f. Diktum}

Diktum dalam suatu peraturan nagari merupakan pernyataan formal yang dikeluarkan lembaga atau pejabat pembuat peraturan nagari yang terdiri dari beberapa komponen, yaitu frase 'persetujuan', kata 'Memutuskan', kata 'Menetapkan', dan kata 'Nama Peraturan Nagari'.

Diktum diawali dengan frase 'Dengan Persetujuan Bersama BADAN MUSYAWARAH NAGARI dan WALI NAGARI' yang diletakkan di tengah margin, diikuti dengan kata 'Memutuskan' yang ditulis seluruhnya dengan huruf besar (kapital) dan diakhiri dengan tanda baca titik dua serta diletakkan di tengah margin. Selanjutnya, setelah kata 'Memutuskan', dicantumkan kata 'Menetapkan' yang disejajarkan ke bawah dengan kata 'Menimbang' dan 'Mengingat', dengan awal huruf ditulis dengan huruf besar (kapital) dan diakhiri dengan tanda baca titik dua. Terakhir, setelah tanda baca titik dua pada kata 'Menetapkan', dicantumkan nama yang tercantum dalam judul peraturan daerah yang ditulis seluruhnya dengan huruf besar (kapital) dan diakhiri dengan tanda baca titik.

\section{Contoh:}


Mengingat $\quad: \quad$............dst

Dengan Persetujuan Bersama

BADAN MUSYAWARAH NAGARI

dan

WALI NAGARI GURUN PANJANG

MEMUTUSKAN:

Menetapkan : PERATURAN NAGARI TENTANG PASAR.

\section{g. Batang Tubuh}

Batang tubuh merupakan bagian inti dari suatu peraturan nagari yang memuat seluruh materi yang diatur dalam peraturan nagari dan dirumuskan dalam pasal-pasal. Pada umumnya substansi peraturan nagari sebagaimana halnya dengan substansi peraturan perundang-undangan yang lain, dikelompokkan ke dalam: 1) Ketentuam Umum; 2) Materi Pokok yang Diatur; 3) Ketentuan Pidana (jika diperlukan); 4) Ketentuan Peralihan (jika diperlukan); dan 5) Ketentuan Penutup. Atas dasar kesamaan materi, pengelompokkan materi peraturan nagari dapat disusun secara sistematis dalam buku, bab, bagian, dan paragraf.

Buku diberi nomor urut dengan bilangan bertingkat dan judul seluruhnya ditulis dengan huruf besar (kapital).

Bab diberi nomor urut dengan angka Romawi dan judul seluruhnya ditulis dengan huruf besar (kapital).

Bagian diberi nomor urut dengan bilangan bertingkat yang ditulis dengan huruf dan diberi judul - huruf awal kata bagian, urutan bilangan, dan setiap kata pada judul bagian ditulis dengan huruf kapital kecuali huruf awal kata partikel yang tidak terletak pada awal frase.

Paragraf diberi nomor urut dengan angka Arab dan diberi judul - huruf awal dari kata paragraf dan setiap kata pada judul paragraf ditulis dengan huruf besar (kapital) kecuali awal kata partikel yang tidak terletak pada awal frase.

Pasal memuat satu norma dan dirumuskan dalam satu kalimat yang disusun secara singkat, jelas, dan lugas dengan diberi nomor urut dengan angka Arab -huruf awal pasal yang digunakan sebagai acuan ditulis dengan huruf besar (kapital) dan dapat dirinci ke dalam beberapa ayat yang diberi nomor urut dengan angka Arab di antara tanda baca kurung tanpa tanda baca titik.

\section{Contoh:}

BUKU PERTAMA

UMUM

$B A B$ II

ASAS, FUNGSI, DAN TUJUAN

Bagian Keempat

Tugas dan Wewenang

Paragraf 1

Ketua, Wakil Ketua, dan Hakim

Pasal 97

Pasal 98

(1) $\ldots \ldots \ldots \ldots$

(2) 


\section{h. Ketentuan Umum}

Ketentuan umum diletakkan dalam BAB I dan dapat memuat lebih dari satu pasal. Jika dalam suatu undangundang tidak dilakukan pengelompokan bab, ketentuan umum diletakkan dalam pasal-pasal awal. Ketentuan umum berisi:

a. Batasan pengertian atau definisi

b. Singkatan atau akronim yang digunakan dalam undang-undang

c. Hal-hal lain yang bersifat umum yang berlaku bagi pasal-pasal berikutnya antara lain ketentuan yang mencerminkan asas, maksud, dan tujuan.

Frase pembuka dalam ketentuan umum peraturan nagari berbunyi : "Dalam Peraturan nagari ini yang dimaksud dengan:". Jika ketentuan umum memuat batasan pengertian atau definisi, singkatan atau akronim lebih dari satu, maka masing-masing uraiannya diberi nomor urut dengan angka Arab dan diawali dengan huruf besar (kapital) serta diakhiri dengan tanda baca titik.

Kata atau istilah yang dimuat dalam ketentuan umum hanyalah kata atau istilah yang digunakan secara berulang-ulang di dalam pasal-pasal selanjutnya. Suatu kata atau istilah yang hanya digunakan satu kali, namun kata atau istilah itu diperlukan pengertiannya untuk suatu bab, bagian atau paragraf tertentu, dianjurkan agar kata atau istilah tersebut diberi definisi.

Jika suatu batasan pengertian atau definisi dari suatu peraturan perundang-undangan yang lebih tinggi perlu dikutip kembali di dalam ketentuan umum suatu peraturan daerah, maka rumusan batasan pengertian atau definisi di dalam peraturan nagari harus sama dengan rumusan batasan pengertian atau definisi yang terdapat di dalam peraturan perundang-undangan yang lebih tinggi yang dilaksanakan tersebut. Urutan penempatan kata atau istilah dalam ketentuan umum mengikuti ketentuan sebagai berikut:

a. Pengertian yang mengatur tentang lingkup umum ditempatkan lebih dahulu dari yang berlingkup khusus.

b. Pengertian yang terdapat lebih dahulu di dalam materi pokok yang idatur ditempatkan dalam urutan yang lebih dahulu.

c. Pengertian yang mempunyai kaitan dengan pengertian di atasnya diletakkan berdekatan secara berurutan.

\section{i. Materi Pokok yang Diatur}

Materi pokok yang diatur ditempatkan langsung setelah bab ketentuan umum. Jika tidak ada pengelompokan bab, materi pokok yang diatur diletakkan setelah pasal-pasal ketentuan umum. Pembagian materi pokok ke dalam kelompok yang lebih kecil dilakukan menurut kriteria yang dijadikan dasar pembagian.

Contoh:

a. Pembagian berdasarkan hak atau kepentingan yang dilindungi, seperti pembagian dalam Kitab Undang-undang Hukum Pidana:

1. Kejahatan terhadap keamanan negara;

2. Kejahatan terhadap martabat presiden; dan

3. Kejahatan terhadap negara sahabat dan wakilnya;

4. ... dan seterusnya.

b. Pembagian berdasarkan urutan/kronologis, seperti pembagian dalam bentuk hukum acara pidana, dimulai dari penyelidikan, penyidikan, penuntutan, dan pemeriksaan di sidang pengadilan tingkat pertama, tingkat banding, tingkat kasasi, dan peninjauan kembali.

c. Pembagian berdasarkan urutan jenjang jabatan, seperti Jaksa Agung, Wakil Jaksa Agung, dan Jaksa Agung Muda.

\section{j. Ketentuan Peralihan (jika diperlukan)}

Ketentuan peralihan di dalam suatu Peraturan Nagari adalah ketentuan-ketentuan yang mengatur mengenai penyesuaian keadaan yang sudah ada pada saat mulai berlakunya Perna yang baru, sehingga dapat berlaku atau tidak membawa dampak yang tidak dikehendaki dalam masyarakat, yang berisi norma peralihan yang berfungsi mengatasi kemungkinan terjadinya kekosongan hukum sebagai akibat peralihan dari ketentuan lama ke ketentuan baru.

Ketentuan peralihan diletakkan dalam Bab Ketentuan Peralihan di antara Bab Ketentuan Pidana dan Bab Ketentuan Penutup. Namun jika dalam sebuah peraturan daerah tidak diadakan pengelompokan bab, pasal yang berisi ketentuan peralihan diletakkan sebelum pasal yang memuat ketentuan penutup. Ketentuan peralihan tidak mutlak harus ada dalam sebuah peraturan daerah dan baru dirumuskan hanya jika diperlukan. 


\section{k. Ketentuan Penutup} memuat:

Ketentuan penutup adalah ketentuan yang menjadi bagian terakhir batang tubuh suatu peraturan nagari, yang

a. Penunjukan organ atau lembaga tertentu yang akan melaksanakan peraturan nagari yang bersangkutan.

b. Nama singkat (citeer title) dan judul kutipan peraturan nagari.

c. Status peraturan nagari yang sudah ada sebelumnya.

d. Saat mulai berlakunya peraturan nagari tersebut.

Dalam hal pemberian 'nama singkat' dan 'judul kutipan' peraturan nagari:

1) Peraturan nagari yang akan diberi nama singkat merupakan peraturan nagari yang memiliki nama yang panjang, sedangkan peraturan nagari yang namanya sudah singkat tidak perlu diberi nama singkat.

2) Nomor dan tahun pengeluaran peraturan nagari yang bersangkutan tidak dicantumkan.

3) Nama singkat bukan berupa singkatan atau akronim, kecuali jika singkatan atau akronim itu sudah sangat dikenal dan tidak menimbulkan salah pengertian.

4) Nama singkat tidak memuat pengertian yang menyimpang dan isi dari nama peraturan.

5) Hindari penggunaan sinonim sebagai nama singkat.

a. Dalam menyatakan 'status peraturan perundang-undangan yang sudah ada':

1) Jika materi dalam peraturan nagari yang baru menyebabkan perlunya penggantian seluruh atau sebagian materi dalam peraturan nagari yang lama, maka di dalam peraturan nagari yang baru harus secara tegas diatur mengenai pencabutan seluruh atau sebagian peraturan nagari yang lama.

2) Peraturan nagari hanya dapat dicabut dengan peraturan nagari atau ketentuan peraturan perundang-undangan yang lebih tinggi hierarkinya.

3) Rumusan pencabutan diawali dengan frase 'Pada saat peraturan daerah ini mulai berlaku kecuali untuk pencabutan yang dilakukan dengan peraturan nagari perlu peraturan nagari pencabutan tersendiri'.

4) Demi kepastian hukum, dalam pencabutan peraturan daerah, disebutkan dengan tegas peraturan daerah mana yang dicabut (tidak dirumuskan secara umum).

5) Untuk mencabut peraturan daerah yang telah diundangkan dan telah mulai berlaku, digunakan frasa 'dicabut dan dinyatakan tidak berlaku'.

b. Dalam hal menyatakan 'saat mulai berlaku peraturan nagari':

1) Pada dasarnya setiap peraturan nagari mulai berlaku pada saat peraturan yang bersangkutan diundangkan.

2) Jika ada penyimpangan terhadap saat mulai berlakunya peraturan nagari yang bersangkutan pada saat diundangkan, hal ini hendaknya dinyatakan secara tegas di dalam peraturan nagari yang bersangkutan tersebut.

3) Hindari frase 'mulai berlaku efektif pada tanggal' atau yang sejenisnya, karena frase ini menimbulkan ketidakpastian mengenai saat resmi berlakunya suatu peraturan nagari, saat pengundangan, atau saat berlaku efektif.

4) Pada dasarnya saat mulai berlakunya peraturan nagari adalah sama bagi seluruh bagian peraturan nagari, dan seluruh wilayah kabupaten/kota. Namun penyimpangan terhadap saat mulai berlaku peraturan nagari hendaknya dinyatakan secara tegas dengan :

a. Menetapkan bagian-bagian mana dalam peraturan nagari itu yang berbeda saat mulai berlakunya.

b. Menetapkan saat mulai berlaku yang berbeda bagi wilayah kabupaten tertentu.

c. Rincian mengenai pengaruh ketentuan berlaku surut terhadap tindakan hukum, hubungan hukum, dan akibat hukum tertentu yang sudah ada perlu dimuat dalam ketentuan peralihan.

d. Awal dan saat mulai berlaku peraturan daerah sebaiknya ditetapkan tidak lebih dahulu dari saat rancangan peraturan daerah tersebut mulai diketahui oleh masyarakat, misalnya: saat rancangan peraturan daerah itu disampaikan ke Dewan Perwakilan Rakyat Daerah.

5) Pada saat mulai berlaku peraturan nagari, pelaksanaannya tidak boleh ditetapkan lebih awal daripada saat mulai berlaku peraturan nagari yang mendasarinya.

\section{l. Penutup}

Penutup merupakan bagian akhir peraturan nagari yang memuat :

- Rumusan tempat dan tanggal penetapan, diletakkan di sebelah kanan

- Nama Jabatan ditulis dengan huruf Kapital dan pada akhir kata diberi tanda baca;

- Nama lengkap pejabat yang menandatangani, ditulis dengan huruf capital tanpa gelar dan pangkat

- Penetapan peraturan Desa ditandatangani oleh Wali Nagari; 


\section{SIMPULAN}

Berdasarkan pembahasan yang telah dilakukan diperoleh beberapa kesimpulan sebagai berikut:

1. Peraturan nagari sama dengan peraturan desa. Peraturan Nagari di Sumatera Barat dibentuk oleh pemerintahan nagari, yang terdiri atas Badan Permusyawaratan (BAMUS) Nagari atau Badan Permusyawaratan Rakyat Nagari (BPRN) bersama Wali Nagari. Kedudukan Peraturan Nagari dalam tata urutan perundang-undangan diakui sebagai salah satu bentuk ketetapan hukum yang mengikat, di mana dalam hal ini pembentukan dan muatan materinya harus disesuaikan dan tidak boleh bertentangan dengan kepentingan umum serta peraturan hukum yang lebih tinggi;

2. Dengan diberlakukannya otonomi daerah, pemerintahan nagari Gurun Panjang berwenang mengatur dan mengurus rumah tangganya sendiri, termasuk dalam pembentukan Peraturan Nagari. Usulan pembuatan Peraturan Nagari dapat berasal dari wali nagari yang kemudian dibahas antara wali nagari dan BAMUS Nagari. Setelah disetujui bersama, maka Peraturan Nagari tersebut kemudian dibawa oleh kepala BAMUS Nagari kepada Wali Nagari untuk ditetapkan (berlaku sejak ditetapkan) dan kemudian disampaikan kepada Bupati melalui Camat sebagai bahan pembinaan dan pengawasan;

3. Sebuah Peraturan nagari terdiri dari beberapa bagian yang tersusun dalam suatu kerangka dan bersifat baku untuk setiap jenis peraturan perundang-undangan. Kerangka Peraturan Nagari terdiri atas 6 (enam) bagian, yaitu: Judul, Pembukaan, Batang Tubuh, Penutup, Penjelasan (jika diperlukan), dan Lampiran (jika diperlukan).

\section{DAFTAR PUSTAKA}

\section{Buku}

Alfar Arbi, Sistem Pemerintahan Nagari di Sumatera Barat, (Padang: Angkasa, 1999).

Deddy Supriady Bratakusumah, Otonomi Penyelenggaraan Pemerintah Daerah, Cet ke-

3 (Jakarta: Gramedia Pustaka Utama, Juni 2002).

Farid Ali, Metode Penelitian Sosial dalam Bidang Ilmu Administrasi Negara dan Pemerintahan, (Jakarta: Raja Grafindo Persada, 1997)

Inu Kencana Syafi'i, Sistem Pemerintahan Indonesia dari Orde Lama Hinggga Era Reformasi, Jakarta: Rineka Cipta, 2007).

Marbun, "Peradilan Administrasi dan Upaya Administratif di Indonesia", Cet ke-1 (Yogyakarta: Liberty,1997).

Otong Rosadi, Hukum Tata Negara Indonesia; Teori dan Praktek, (Naskah Untuk Program Penulisan Buku Teks Perguruan Tinggi), (Padang: Fakultas Hukum Universitas Ekasakti, 2004).

Ronny Hanitijo Soemitro, Metodologi Penelitian Hukum dan Jurimetri, Cetakan Kelima, Jakarta: Ghalia Indonesia, 1994).

Soerjono Soekanto, Faktor-faktor yang Mempengaruhi Penegakan Hukum, (Jakarta: PT Raja Grafindo Persada, 2004).

\section{Jurnal}

Amrah Muslimin, Otonomi Daerah: Antara Cita dan Realita, Jurnal Sosial Politik Dialektika, Vol. 29 No. 29 (Juli 2009).

\section{Peraturan Perundang-Undangan}

Undang-Undang Dasar Negara Republik Indonesia Tahun 1945.

Undang-Undang Nomor 10 tahun 2004 tentang Pembentukan Peraturan Perundang-Undangan Negara Republik Indonesia yang telah dirubah dengan Undang-Undang Nomor 12 Tahun 2011 dan Undang-Undang Nomor 15

Tahun 2019 tentang Perubahan Atas Undang-Undang Nomor 12 Tahun 2011 tentang Pembentukan Peraturan Perundang-Undangan.

Undang-Undang Nomor 6 Tahun 2014 tentang Desa.

Peraturan Daerah Provinsi Sumatera Barat Nomor 2 Tahun 2007 tentang Pokok-Pokok Pemerintahan Nagari.

Peraturan Daerah Kabupaten Pesisir Selatan Nomor 9 Tahun 2010 tentang Perubahan Atas Peraturan Daerah Kabupaten Pesisir Selatan Nomor 8 Tahun 2007 tentang Pemerintahan Nagari. 